Endocrinol. Japon. 1967, 14 (1), 7〜10

\title{
CHANGES OF URINARY STEROIDS FOLLOWING MAJOR SURGICAL STRESS
}

\author{
TOHRU UOZUMI, HideYuKi TANAKA AND YUJI HAMANAKA \\ First Department of Surgery, Osaka University \\ Medical School, Osaka \\ TOKUICHIRO SEKI \\ Department of Genetics, Osaka University \\ Medical School, Osaka \\ Keishi MATSUMOTO ANd Akiyuki AKEHI \\ Department of Pathology, Osaka University \\ Medical School, Osaka
}

\begin{abstract}
SYNOPSIS
Quantitative determinations of urinary 17-hydroxycorticosteroids and 17-ketosteroids were made in 12 patients with pulmonary tuberculosis before and 3 weeks to 8 months after pulmonary lobectomy. Fifteen normal males and 5 normal females were used as controls. The urinary excretion of 17hydroxycorticosteroids of the patients remained almost unchanged several months or more postoperatively but the excretion of urinary 17-ketosteroids showed a gradual and significant decrease in the same period. It was also demonstrated that the ratios of etiocholanolone to androsterone and tetrahydrocortisone + tetrahydrocortisol + cortisol to allotetrahydrocortisol increased significantly following operation, even 6 to 8 months after surgical stress. It is suggested that these findings of urinary steroids following operation may reflect some of the nonspecific metabolic responses to a major surgical stress.
\end{abstract}

It has been well known that excretion of 17-hydroxycorticosteroids (17-OHCS) increases remarkably from 1 to 3 days after surgical stress. But quantitative and qualitative changes of urinary steroids in a relatively late postoperative stage, e.g., several weeks or months after operation, seem to be unclarified. In such a late stage, most patients, being free from surgical stress, are likely to have a clinical convalescence. This paper deals with the analytical data of urinary 17-OHCS and 17-ketosteroids (17$\mathrm{KS}$ ) in later stages following major surgical operations.

\section{MATERIALS AND METHODS}

\section{Materials}

Twelve males with pulmonary tuberculosis who had been admitted to the Toneyama Hospital for pulmonary lobectomy, aged 19 to 53, were studied. As controls, 15 normal males, aged 26 to 40 , and 5 normal females, aged 25 to 40 , were studied. None of the cases examined showed abnormalities of cardiac, renal, hepatic or endocrinological functions on routine tests. The liver function of some patients was slightly disturbed in the postoperative course but no patients showed visible jaundice.

Received for publication October 5, 1966. 


\section{Methods}

The methods for quantitative determinations of urinary $17-\mathrm{OHCS}$ and $17-\mathrm{KS}$ were described in detail in the previous report (Okano et al., 1963). They included enzyme hydrolysis, ethyl acetate extraction, solvolysis, the separation of the ketonic fraction with Girard's reagent and the separation of individual steroids with elution chromatography on partially esterified Amberlite IRC-50 using a mixture of ethanol, methanol and water $(9: 3: 8$, by vol.). The separation of individual fractions of $17-\mathrm{KS}$ found in the adult urine was satisfactory but not that of 17-OHCS, because tetrahydrocortisone (THE), tetrahydrocortisol (THF) and cortisol $(F)$ were eluted together into the same fraction.

\section{RESULTS}

Urinary $17-\mathrm{OHCS}$ and $17-\mathrm{KS}$ in cases of pulmonary tuberculosis before and after operation and in normal males were quantitatively determined (Tables 1 and 2). Total 17-OHCS in cases of tuberculosis before operation was slightly higher than that of normal males, showing no significant differ- ence. No significant differences in total 17$\mathrm{OHCS}$ were found before and after operation. But total 17-KS gradually and significantly decreased in the 2 nd to the 8 th month after operation, while total $17-\mathrm{KS}$ before surgery was almost equal to that of normal males.

It was noted that the ratio of $5 \beta-\mathrm{H}$-steroids to $5 \alpha$-H-steroids pre- and postoperatively changes markedly. A ratio of etiocholanolone to androsterone significantly increased postoperatively, as did the ratio of THE + $\mathrm{THF}+\mathrm{F}$ to allotetrahydrocortisol (alloTHF) (Table 3). On the other hand, the ratio of etiocholanolone to androsterone was almost unchanged for 2 to 6 months in each of the healthy individuals. (Table 4).

\section{DISCUSSION}

Endocrinological studies during surgical stress have been reported by many workers. Excellent data have been presented concerning about steroid biosynthesis and metabolism for a short period following operation (Thorn et al., 1953; Moore, 1957; Herrman et al., 1959). But no reports of a qualitative and quantitative analysis of urinary steroids

Table 1. Analytical data of urinary 17-OHCS in patients with pulmonary tuberculosis before and after operation

$(\mu \mathrm{g} / 24$ hrs. $)(\mathrm{M} \pm$ S.E. $)$

\begin{tabular}{|c|c|c|c|c|c|c|}
\hline Cases & No. & $6 \beta-\mathrm{OH}-\mathrm{F}$ & $\mathrm{THE}+\mathrm{THF}+\mathrm{F}$ & alloTHF & THS & Total $17-\mathrm{OHCS}$ \\
\hline \multicolumn{7}{|l|}{$\begin{array}{l}\text { Patients with } \\
\text { pulmonary tbc. } \\
\text { aged } 19-53\end{array}$} \\
\hline before & \multirow[t]{2}{*}{12} & 60 & 2638 & 509 & 40 & 3247 \\
\hline operation & & \pm 17 & \pm 364 & \pm 98 & \pm 10 & \pm 432 \\
\hline 3 weeks & \multirow[t]{2}{*}{10} & 128 & 3749 & 311 & 49 & 4237 \\
\hline after op. & & \pm 32 & \pm 680 & \pm 71 & \pm 17 & \pm 762 \\
\hline 2 months & \multirow[t]{2}{*}{11} & 55 & 2014 & 212 & 26 & 2307 \\
\hline after op. & & \pm 15 & \pm 437 & \pm 62 & \pm 9 & \pm 489 \\
\hline 6-8 months & \multirow[t]{2}{*}{8} & 44 & 2358 & 249 & 41 & 2691 \\
\hline after op. & & \pm 16 & \pm 348 & \pm 51 & \pm 10 & \pm 375 \\
\hline \multirow{2}{*}{$\begin{array}{l}\text { Normal Males } \\
\text { aged } 26-40\end{array}$} & \multirow[t]{2}{*}{10} & 148 & 1869 & 271 & 64 & 2351 \\
\hline & & \pm 33 & \pm 140 & \pm 37 & \pm 12 & \pm 177 \\
\hline Abbreviations: & & & $\mathrm{F}$ & : Col & & \\
\hline $6 \beta-\mathrm{OH}-\mathrm{F} \quad:$ & $6 \beta$-hydr & cortisol & alloTHF & : Allc & Arocor & \\
\hline THE & Tetrahy & ocortisone & THS & : Tetra & 11-desc & cortisol \\
\hline
\end{tabular}


Table 2. Analytical data of urinary 17-KS in patients with pulmonary tuberculosis before and after operation $\quad(\mu \mathrm{g} / 24 \mathrm{hrs}).(\mathrm{M} \pm$ S.E. $)$

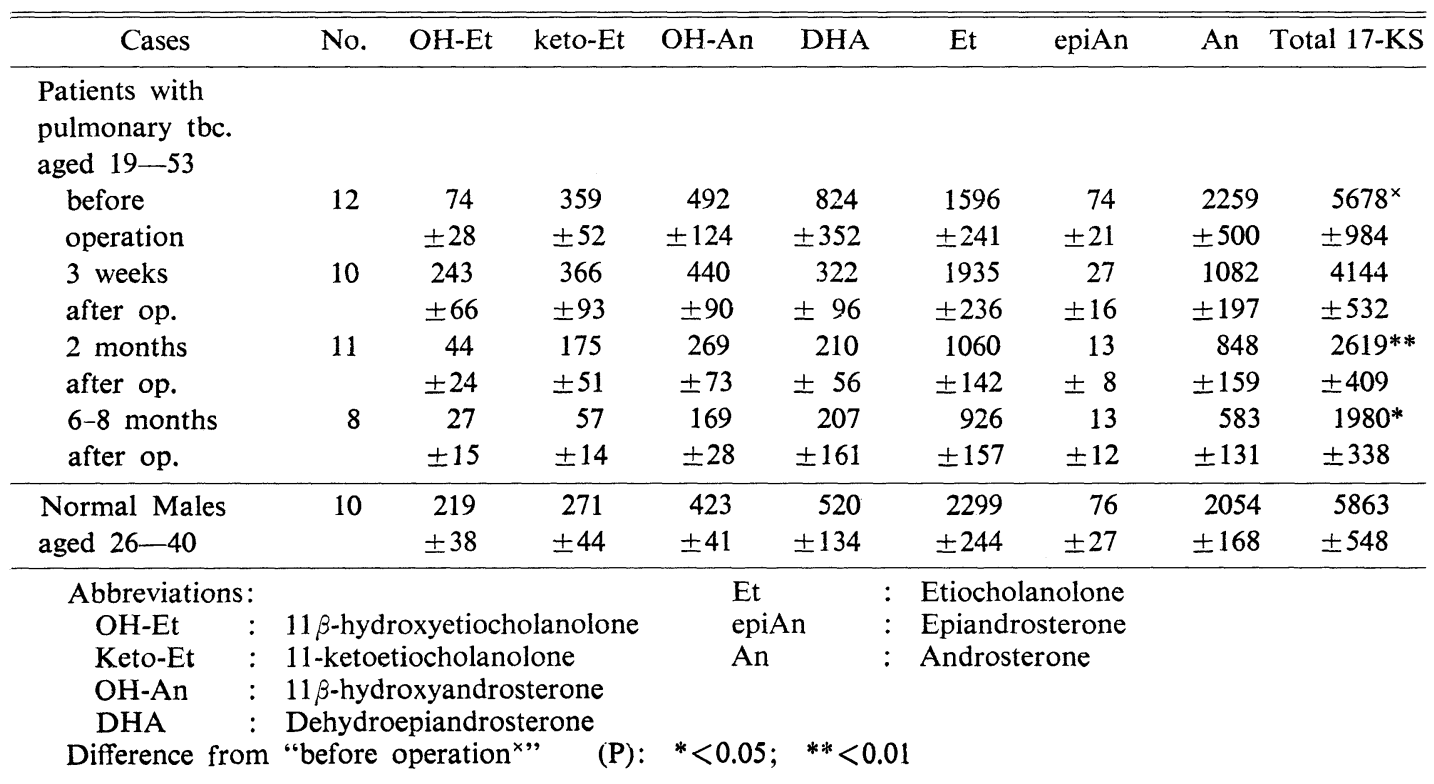

Table 3. Ratios of urinary etiocholanolone to androsterone and of THE $+\mathrm{THF}+\mathrm{F}$ to alloTHF

$(\mathrm{M} \pm$ S.E. $)$

\begin{tabular}{|c|c|c|c|}
\hline Cases & No. & $\frac{\text { Etiocholanolone }}{\text { Androsterone }}$ & $\frac{\mathrm{THE}+\mathrm{THF}+\mathrm{F}}{\text { alloTHF }}$ \\
\hline \multicolumn{4}{|l|}{$\begin{array}{l}\text { Patients with } \\
\text { pulmonary } \\
\text { tbc. aged } \\
19-53\end{array}$} \\
\hline $\begin{array}{l}\text { before } \\
\text { operation }\end{array}$ & 12 & $\begin{aligned} & 0.9^{\times} \\
\pm & 0.1\end{aligned}$ & 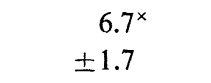 \\
\hline $\begin{array}{l}3 \text { weeks } \\
\text { after op. }\end{array}$ & 10 & $\begin{aligned} & 2.2^{* * *} \\
\pm & 0.4\end{aligned}$ & $\begin{array}{l}18.7^{* *} \\
\pm 4.1\end{array}$ \\
\hline $\begin{array}{l}2 \text { months } \\
\text { after op. }\end{array}$ & 11 & $\begin{aligned} & 1.5^{* *} \\
\pm & 0.3\end{aligned}$ & $\begin{array}{l}11.9^{*} \\
\pm 2.7\end{array}$ \\
\hline $\begin{array}{l}\text { 6-8 months } \\
\text { after op. }\end{array}$ & is 8 & $\begin{aligned} & 1.9^{*} \\
\pm & 0.3\end{aligned}$ & $\begin{array}{r}13.6 \\
\pm 3.2\end{array}$ \\
\hline $\begin{array}{l}\text { Normal } \\
\text { males } \\
\text { aged 26-40 }\end{array}$ & $0^{10}$ & $\begin{array}{r}1.1 \\
\pm 0.1\end{array}$ & $\begin{aligned} & 8.5^{*} \\
\pm & 1.6\end{aligned}$ \\
\hline
\end{tabular}

Difference from "before operation" $\times(\mathrm{P})$ : $*<0.05 ; \quad * *<0.01$ in later postoperative periods, e.g., 2 to 8 months after operation seem to have appeared.

It was found in the present study that the urinary excretion of 17-OHCS was almost unchanged in the late postoperative stage, but urinary $17-\mathrm{KS}$ decreased gradually and remarkably in the same period. Thus it is suggested that secretion of androgens from the adrenal cortex and/or the testis decreased significantly in the late postoperative stage, while a secretion of cortisol remained nearly unchanged.

The ratio of $5 \beta-\mathrm{H}$-steroids to $5 \alpha-\mathrm{H}$-steroids increased significantly even 6 to 8 months after surgical stress, probably because of a relatively increased activity of 5B-reductase in the liver. The ratio of etiocholanolone to androsterone remained unchanged for 2 to 6 months in all healthy individuals (Table 4), as reflected in a report by $\mathrm{McK}$. Jefferies and Michelakis (1963).

Similar findings of thymectomized patients with myasthenia gravis in our laboratory were previously reported (Takeda et al., 
Table 4. Ratio of urinary etiocholanolone to androsterone of healthy adult individuals during 2 to 6 months

\begin{tabular}{|c|c|c|c|}
\hline $\begin{array}{c}\text { Normal } \\
\text { Case }\end{array}$ & Sex & Age & $\begin{array}{c}\text { Etiocholanolone } \\
\text { Androsterone }\end{array}$ \\
\hline A & male & 34 & $\begin{array}{l}0.7 \\
0.8 \\
0.7\end{array}$ \\
\hline B & - & 35 & $\begin{array}{l}0.9 \\
0.8 \\
0.8\end{array}$ \\
\hline$C$ & - & 30 & $\begin{array}{l}1.1 \\
1.0\end{array}$ \\
\hline D & - & 34 & $\begin{array}{l}1.9 \\
2.0\end{array}$ \\
\hline$E$ & - & 25 & $\begin{array}{l}1.0 \\
1.2\end{array}$ \\
\hline$F$ & - & 33 & $\begin{array}{l}1.2 \\
1.3\end{array}$ \\
\hline $\mathrm{G}$ & - & 30 & $\begin{array}{l}0.8 \\
0.9\end{array}$ \\
\hline $\mathrm{H}$ & - & 33 & $\begin{array}{l}1.6 \\
1.7\end{array}$ \\
\hline I & - & 26 & $\begin{array}{l}0.7 \\
0.8\end{array}$ \\
\hline $\mathbf{J}$ & - & 26 & $\begin{array}{l}1.0 \\
0.9\end{array}$ \\
\hline
\end{tabular}

\begin{tabular}{|c|c|c|c|}
\hline $\begin{array}{l}\text { Normal } \\
\text { Case }\end{array}$ & Sex & Age & $\begin{array}{c}\text { Etiocholanolone } \\
\text { Androsterone }\end{array}$ \\
\hline $\mathrm{K}$ & male & 28 & $\begin{array}{l}1.0 \\
1.0 \\
1.3\end{array}$ \\
\hline L & - & 31 & $\begin{array}{l}1.1 \\
1.3\end{array}$ \\
\hline$M$ & - & 28 & $\begin{array}{l}1.5 \\
1.3\end{array}$ \\
\hline $\mathrm{N}$ & - & 26 & $\begin{array}{l}1.2 \\
1.0\end{array}$ \\
\hline $\mathrm{O}$ & - & 35 & $\begin{array}{l}1.7 \\
2.0\end{array}$ \\
\hline$P$ & female & 32 & $\begin{array}{l}1.4 \\
1.5\end{array}$ \\
\hline$Q$ & - & 30 & $\begin{array}{l}1.3 \\
1.3 \\
\end{array}$ \\
\hline $\mathrm{R}$ & - & 32 & $\begin{array}{l}1.4 \\
1.4\end{array}$ \\
\hline$S$ & - & 25 & $\begin{array}{l}2.3 \\
2.7\end{array}$ \\
\hline $\mathrm{T}$ & - & 40 & $\begin{array}{l}1.1 \\
1.1\end{array}$ \\
\hline
\end{tabular}

1964). It may be suggested that the above changes of urinary steroids reflect a nonspecific response of steroid biosynthesis and metabolism to a major surgical stress. However, the reason for these changes is not understood.

\section{SUMMARY}

Quantitative determinations of urinary steroids in 12 patients with pulmonary tuberculosis before and three weeks to eight months after pulmonary lobectomy were reported. Fifteen normal males and five normal females were used as controls.

The urinary excretion of 17-hydroxycorticosteroids remained almost unchanged several months or more postoperatively but the excretion of urinary 17-ketosteroids showed a gradual and significant decrease in the same period.

It was also demonstrated that the ratio of etiocholanolone to androsterone and tetrahydrocortisone + tetrahydrocortisol +

cortisol to allotetrahydrocortisol increased significantly following operation, even 6 to 8 months after surgical stress.

It is suggested that the above findings of urinary steroids following operation may reflect some of the nonspecific metabolic responses to a major surgical stress.

\section{REFERENCES}

Herrman, W.L., M.A. Hayes, I.S. Goldenberg and I.K. Shindle (1959). J. Clin. Endocrinol. and Metabolism 19, 849.

McK. Jefferies, W. and A.M. Michelakis (1963). Metabolism 12, 1017.

Moore, F.D. (1957). Recent Progr. in Hormone Research 13, 511.

Okano, K., K. Matsumoto, A Akehi, S. Mizutani, H. Kikkawa and T. Seki (1963). Endocrinol. Japon. 10, 221.

Takeda, Y., S. Yoshida, T. Uozumi, R. Nozaki, M. Kajimura, K. Matsumoto and T. Seki (1964). ibid. 11, 237.

Thorn, G.W., J. Dalton and J.C. Laidlaw (1953). Recent Progr. in Hormone Research 8, 171. 